\section{Predicting Nitrogen Availability in Irrigated Potato Systems}

\author{
S.S. Snapp ${ }^{1}$ and A.M. Fortuna ${ }^{2}$
}

Additional INDEX WORDs. crop simulation, modeling, DSSAT, nitrogen mineralization, Solanum tuberosum

Summary. Growers lack practical decision aides that accurately predict nitrogen $(\mathrm{N})$ credits for organic sources to adjust fertilizer rates. The simulation model, DSSAT, was used to predict $\mathbf{N}$ supply in relationship to $\mathbf{N}$ demand in irrigated potatoes (Solanum tuberosum). Tuber yield and soil inorganic $\mathrm{N}$ levels were substantially higher in the simulations than in field experiment observations, indicating the need for model improvement. DSSAT was successful at predicting relative mineralization rates and potato $\mathrm{N}$ uptake for different organic and inorganic $\mathbf{N}$ source combinations. Interestingly, both simulation and field experiment observations indicated that combining a high quality organic manure at $5000 \mathrm{lb} /$ acre $\left(5604.2 \mathrm{~kg} \cdot \mathrm{ha}^{-1}\right)$, total applied N 250 $\mathrm{lb} /$ acre $\left(280.2 \mathrm{~kg} \cdot \mathrm{ha}^{-1}\right)$, and a fertilizer source of $\mathrm{N} 160 \mathrm{lb} /$ acre $(179.3$ $\left.\mathrm{kg} \cdot \mathrm{ha}^{-1}\right)$ markedly increased yields and lowered leaching potential. Simulated tuber yield for the combined treatment was $660 \mathrm{cwt} /$ acre $\left(74.0 \mathrm{t} \cdot \mathrm{ha}^{-1}\right)$ with $48 \mathrm{lb} /$ acre $\left(53.8 \mathrm{~kg} \cdot \mathrm{ha}^{-1}\right)$ inorganic- $\mathrm{N}$ in the profile at harvest, whereas the highest simulated $\mathrm{N}$ fertilizer response was to $235 \mathrm{lb} /$ acre $\left(263.4 \mathrm{~kg} \cdot \mathrm{ha}^{-1}\right)$, which produced $610 \mathrm{cwt} /$ acre $(68.4$ t.ha $\left.{ }^{-1}\right)$ with $77 \mathrm{lb} /$ acre $\left(86.3 \mathrm{~kg} \cdot \mathrm{ha}^{-1}\right)$ inorganic- $\mathrm{N}$ in the profile at harvest. The synchrony of $\mathbf{N}$ release and uptake for combined manure and fertilizer treatments may explain the efficient $\mathbf{N}$ uptake observed. Common soil types and weather scenarios in Michigan were simulated and indigenous soil $\mathrm{N}$ mineralization was predicted to be 6 $\mathrm{lb} /$ acre $\left(6.7 \mathrm{~kg} \cdot \mathrm{ha}^{-1}\right)$ inorganic- $\mathrm{N}$ in the topsoil at planting, similar to observed levels. The increasing aeration associated with a sandy versus a sandy loam soil only slightly increased the predicted rate of mineralization from

Michigan State University, East Lansing, MI 48824.

${ }^{1}$ Department of Horticulture, Michigan State University, East Lansing, MI 48824-1325.

${ }^{2}$ Department of Crop and Soil Sciences, Michigan State University, East Lansing, MI 48824-1325. organic inputs. Simulated soil inorganic $\mathrm{N}$ levels with different organic inputs was modestly increased in a warm spring $\left[4.5^{\circ} \mathrm{F}\left(2.50{ }^{\circ} \mathrm{C}\right)\right.$ over normal temperatures] compared to a cool spring $\left(-4.5^{\circ} \mathrm{F}\right.$ less than normal temperatures). For Michigan irrigated potato systems, DSSAT simulations indicate that the most important factor determining inorganic $\mathrm{N}$ supply will be the quality and quantity of organic inputs, not environmental conditions.

A ccurate prediction of $\mathrm{N}$ availability is the basis for optimizing synchronization of N supply and potato uptake demand, critical to insuring high tuber yield and quality. Inadequate $\mathrm{N}$ can limit tuber size and marketable yield, allow weeds to compete with the crop, and enhance the susceptibility to the early die complex (Lang et al, 1999; Rosen, 1991). The potato plant's shallow root system contributes to its high fertilizer demand (Opena and Porter, 1999). This can pose an environmental challenge, as research on Michigan cropping systems has shown that $\mathrm{N}$ fertilizer application levels in excess of $300 \mathrm{lb} /$ acre $\left(336.2 \mathrm{~kg} \cdot \mathrm{ha}^{-1}\right)$ $\mathrm{N}$ can lead to significant leaching losses into water supplies and/or ammonia losses to the atmosphere (Christenson et al., 1992; Chu etal., 1997). Optimizing $\mathrm{N}$ applied will not only protect against excess $\mathrm{N}$ loss to the environment, it will also improve agronomic performance as excess $\mathrm{N}$ supply at planting can delay tuber growth, reduce yields, and lower specific gravity (Griffin and Hesterman, 1991). Further, excess $\mathrm{N}$ during tuber bulking can delay maturity of tubers and adversely affect tuber storability and quality (Ojala et al., 1990).

Predicting soil indigenous N supply, and the rate of mineralization of organic $\mathrm{N}$ sources, are key challenges that growers face. Recent reviews on improving $\mathrm{N}$ efficiency in cropping systems, and management of nitrogen and water in potato systems in particular, prioritize application of models to develop practical tools and predict soil N supply in relationship to crop demand (Cassman et al., 2002; Haverkort and MacKerron, 2000; Raun and Johnson, 1999). Environmental conditions and soil management all influence the size of the available $\mathrm{N}$ pool. Mineralization is influenced by the type of tillage used, the source and quality of organic residues present, and inorganic fertilization strategies. Influential bio-physical environmental factors include soil organic matter, temperature, $\mathrm{pH}$, soil moisture, soil texture (which influences aeration and diffusion of substrate for soil microorganisms) and soil community ecology (Olness et al., 2001). There are excellent reviews of the $\mathrm{N}$ transformation processes involved that can be consulted for in-depth discussion (Cassman et al., 2002; Jansson and Persson, 1982).

Efforts to predict $\mathrm{N}$ supply from soil include models based on mathematical functions that describe observed interaction of soil organic matter, aeration and soil texture (Olness et al., 2001) and temperature-based models (Griffin and Honeycutt, 2000; Honeycutt and Potaro, 1990). Simulation models that predict $\mathrm{N}$ release generally incorporate two or more organic matter pools with different decay constants. These may be calibrated through field-based or microcosm studies of decomposition (Godwin and Jones, 1999; Henricksen and Breland, 1999); and models that combine simulation of crop growth with simulation of soil $\mathrm{N}$ and water processes, such as DSSAT and CERES (Paz et al., 1999; Snapp et al., 2001; Tsuji et al., 1994). Controlled environment studies have shown excellent predictive capacity, where water filled pore space has been shown to be closely related to microbial respiration rate and nitrate formation, or thermal units used to accurately predict $\mathrm{N}$ mineralization from a range of organic sources (Griffin and Honeycutt, 2000; Henricksen and Breland, 1999). The application of models to predict nitrate formation in the field environment has had more variable success (Linn and Doran, 1984; Olness et al., 2001; Paz et al., 1999).

Growers use practices that improve $\mathrm{N}$ efficiency, such as split applications of $\mathrm{N}$ fertilizer to match supply to crop demand, but there is a lack of information on how climate and soil conditions, as well as type of organic $\mathrm{N}$ sources used, interact to determine soil $\mathrm{N}$ supply for a given season and crop. A survey indicated that over three-quarters of Michigan potato growers recognize the value in applying $\mathrm{N}$ through multiple, split applications and in using petiole- $\mathrm{N}$ monitoring to evaluate plant $\mathrm{N}$ status and modify fertilizer use (Snapp et al., 2001). However, this survey also highlighted the lack of confidence growers have in the practice of estimating $\mathrm{N}$ supply from manure, forage rotations or soil mineralization using $\mathrm{N}$ fertilizer credit equivalents, which are recommended to be subtracted from the total amount of 
fertilizer applied. A survey of US faculty showed that manure $\mathrm{N}$ crediting is only being used on $18 \%$ to $54 \%$ of manured fields, indicating that fertilizer rates are frequently not adjusted to take into account nutrients applied with manure (Schmitt et al., 1999).

Improved decision aides are urgently needed by growers, crop advisors and extension agents to estimate availability of inorganic $\mathrm{N}$ in soil. Application of manure, use of winter cover crops and legume residues from forage rotation systems are starting to be experimented with by potato growers in Michigan (Snapp et al., 2003). A barrier to wider use of organic nutrient sources is the lack of reliable means to predict when $\mathrm{N}$ will be mineralized from these sources. This is a critical issue in high value vegetable crops where $\mathrm{N}$ can influence quality as well as quantity.

The objectives of this study were to 1 ) test the use of DSSAT as a predictor of $\mathrm{N}$ supply and crop demand in an irrigated potato system; 2 ) evaluate the effect of temperature and soil texture on inorganic- $\mathrm{N}$ dynamics and uptake in potatoes; and 3) compare predicted $\mathrm{N}$ mineralization from organic sources with and without the addition of inorganic $\mathrm{N}$ from fertilizer.

\section{Materials and methods}

Simulations. DSSAT was selected as the most widely used crop/ environmental growth model that includes subroutines that simulate potato crop growth and irrigated conditions. DSSAT is a process-based, dynamic simulation program that uses common subroutines for modeling water and $\mathrm{N}$ processes in soil, in conjunction with modules for different crop types. SUBSTOR is the module used for root and tuber crops, including potato (Griffin et al., 1993). A strength of DSSAT version 3.5 is that it includes parameters for a large number of cultivars of 16 different crop types (Huffman, et al., 2001). To parameterize the model we selected the determinate cultivar, Atlantic, which is a widely grown chip-processing cultivar with a mid-season growth duration of about 110 d (Love, 1999). 'Pike' was used in a field experiment for comparison purposes, and 'Atlantic' was the closest available cultivar (similar growth duration and adapted to Michigan growing conditions) that was parameterized for the model.
DSSAT version 3.5 potato subroutine Substor-Potato 3.5 was used to simulate potato growth and soil $\mathrm{N}$ dynamics in an irrigated system. Two soil types were compared in the simulations, a sandy loam soil based on a Oshtemo sandy loam, with parameters taken from the taxonomic information collected at the Living Field Laboratory, Kellogg Biological Station, Hickory Corners, Michigan (Table 1). The deep sand soil was based on a Millhopper Fine Sand. These soil types have low organic carbon levels, are coarse textured and well drained, thus representative of the majority of potato production areas in the north central U.S. (Table 1).

The plant population density and recommended fertilizer rate of 200 $\mathrm{lb} /$ acre $\left(224.2 \mathrm{~kg} \cdot \mathrm{ha}^{-1}\right) \mathrm{N}$ for 'Atlantic' and 'Pike' was based on a decade of research experience (Vitosh et al, 1998) and recently verified through 3 years of research and on-farm trials (Snapp et al., 2002). The same source was used to calculate $\mathrm{N}$ credits and adjust downward the fertilizer $\mathrm{N}$ applied with organic $\mathrm{N}$ sources: a $10 \mathrm{lb} /$ acre $\left(11.2 \mathrm{~kg} \cdot \mathrm{ha}^{-1}\right) \mathrm{N}$ credit for the rye (Secale cereale) cover crop and a $40 \mathrm{lb} /$ acre $\left(44.8 \mathrm{~kg} \cdot \mathrm{ha}^{-1}\right) \mathrm{N}$ credit for the manure applied.

Table 1. Crop and soil characteristics and nitrogen $(\mathrm{N})$ management from a field experiment and DSSAT simulation runs for a deep sand and a sandy loam soil. The field experiment was carried out in 2002 on a McBride/Montcalm sandy loam at Montcalm Research Farm, in central Michigan (Snapp et al., 2003).

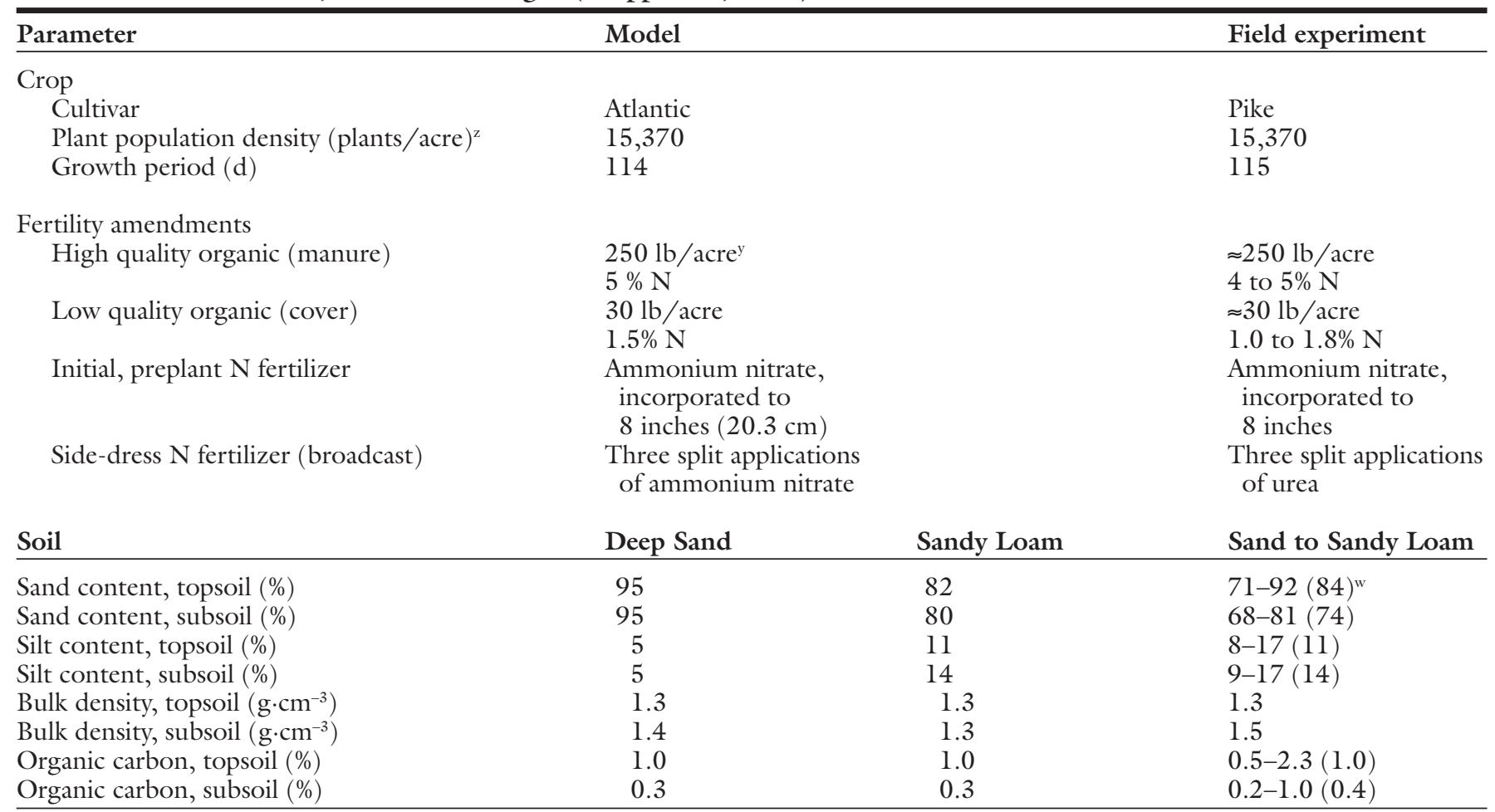

${ }^{\mathrm{z}} 1$ plant $/$ acre $=2.47$ plants $/$ ha.

$\mathrm{y}_{1} \mathrm{lb} / \mathrm{acre}=1.12 \mathrm{~kg} \cdot \mathrm{ha}^{-1}$.

${ }^{\mathrm{w}}$ Observed range and average in parentheses of soil characteristics at Montcalm Research Farm. 
Characterization of organic inputs (cover crop residues and manure) was implemented in the SOILN980.SOL file of DSSAT 3.5 , by adjusting parameters for the decomposition of plant residue. Plant and manure residues are broken into percent carbohydrate, cellulose and lignin in the tissue. Each of these three pools has a decomposition rate with a daily time step for amount decomposed. Crop residue materials are assumed to have $35.4 \%$ carbohydrate, $64.6 \%$ cellulose, and $7.6 \%$ lignin. The decomposition rates of these pools are set at 0.2000 , 0.0500 , and 0.0095 , respectively per day (Godwin and Jones, 1999). In our study an extra line was added in the file for the manure parameters, dividing manure into three pools: the first contained $25 \%$ of the material and a decomposition rate of 0.0490 , the second $10 \%$ and 0.0110 and the third $65 \%$ and 0.0047 , respectively (Gale and Gilmour, 1986).

The irrigation subroutine used was set to automatically irrigate from planting to maturity. The profile was refilled when available soil water was less than $80 \%$. The depth at which available soil water was monitored was set to 19.7 inches $(0.50 \mathrm{~m})$ in the sandy loam and 9.8 inches $(0.25 \mathrm{~m})$ in the fine sand. The irrigation depth was 11.8 inches $(0.30 \mathrm{~m})$ on both soil types.

The 1993 weather file from Kellogg Biological Station was selected after reviewing a set of weather files from 1989 through 1999 to select a representative weather file with temperature maximum and minimum that are similar to long term monthly averages. The summarized weather data can be found on the National Climatic Data Center web site [National Oceanic and Atmospheric Administration (NOAA), 2003]. A modified 1993 weather file was created to simulate a cool spring by subtracting $4.5^{\circ} \mathrm{F}$ from the daily maximum and minimum for the first $120 \mathrm{~d}$ of the year, and in the same manner a warm spring file was created by adding $4.5^{\circ} \mathrm{F}$ to the daily maximum and minimum.

Field experiment. At the Montcalm Research Farm in central Michigan (lat. $43^{\circ} 20^{\prime} \mathrm{N}$; long. $85^{\circ} 01^{\prime} \mathrm{W}$ ), potato tuber yield response of 'Pike' was evaluated for manure and a rye winter cover crop and no inputs, compared to the recommended $\mathrm{N}$ fertilizer rate, $200 \mathrm{lb} /$ acre (Snapp et al., 2002). The soil type is an alfisol, a Montcalm/McBride loamy sand to sandy loam with organic carbon levels as shown in Table 1.

A split plot design with four replicates was used, with a potato snap bean rotation with bare winter fallow versus rye cover crop as the main plot and manure treatment as the sub-plot. Plot size was six rows by $50 \mathrm{ft}(15.24 \mathrm{~m})$. Seed pieces of 'Pike' were planted at 12 inches $(30.5 \mathrm{~cm})$ apart within row, and 34 inches $(86.4 \mathrm{~cm})$ spacing between rows for a plant population of 15,370 plants/acre $(37,979$ plants/ha) on 10 May 2002 (Table 1). The planting date was $40 \mathrm{~d}$ after a $5000 \mathrm{lb} /$ acre poultry composted manure treatment was applied to half of each plot and incorporated. Total manure $\mathrm{N}$ applied was 250 $\mathrm{lb} / \mathrm{acre}$, with estimated availability at $40 \mathrm{lb} /$ acre $\left(44.8 \mathrm{~kg} \cdot \mathrm{ha}^{-1}\right) \mathrm{N}$ in the first season (Nyiraneza, 2003) and total rye cover crop N (root plus shoot residues) was estimated from biomass sampling as $30 \mathrm{lb} /$ acre $\left(33.6 \mathrm{~kg} \cdot \mathrm{ha}^{-1}\right)$ N. Preplant fertilizer was applied according to soil test and recommended rates, potassium broadcast at $180 \mathrm{lb} /$ acre $\left(201.7 \mathrm{~kg} \cdot \mathrm{ha}^{-1}\right)$ and phosphate at 34 $\mathrm{lb} /$ acre $\left(38.1 \mathrm{~kg} \cdot \mathrm{ha}^{-1}\right.$ ) (Snapp et al., 2002). Nitrogen fertilizer was applied as a pre-plant broadcast fertilizer, and three split applications of urea for a total of $200 \mathrm{lb} /$ acre N applied. Supplemental overhead irrigation was used as required and Michigan recommended pest and weed control measures were followed. A two-row harvester was used and tubers were graded on a grading line into size classes including Bs $[<1.875$ inches $(4.7625 \mathrm{~cm})]$, oversized tubers $[>3.25$ inches $(8.255$ $\mathrm{cm}$ )] and US\#ls (between 1.875 and 3.25 inches). Internal defects and specific gravity was determined on a subsample (Snapp et al., 2003).

Soil sampling was conducted using four 2 -inch $(5.1-\mathrm{cm})$ core composites per plot at three depths: 0 to 8 inches $(20.3 \mathrm{~cm}), 8$ to 20 inches $(50.8 \mathrm{~cm})$, and 20 to 32 inches $(81.3$ $\mathrm{cm})$. Samples were stored in the refrigerator, dry weights determined for a sub-sample to allow correction for fresh weight, and fresh samples were extracted in $1 \mathrm{~m}$ potassium chloride and nitrate and ammonia determined through ion chromatography using an OI Analytical Flow Solution IV (Alpkem, College Station, Texas).

Table 2. Simulated and observed yields of irrigated potato production response to organic amendments, with and without nitrogen $(\mathbf{N})$ fertilizer application. Soil and crop parameters are presented in Table 1. Observed data is an average and standard deviation (in parentheses) of trials carried out in central Michigan over 2001 and 2002 (Snapp et al., 2003).

\begin{tabular}{|c|c|c|c|c|c|}
\hline Amendment & $\begin{array}{c}\text { Organic } \\
\text { amendment } \\
\text { total } \mathrm{N} \text { input }\end{array}$ & $\begin{array}{c}\text { Fertilizer } \\
\mathrm{N} \\
\text { input }\end{array}$ & $\begin{array}{l}\text { Simulated } \\
\text { yield } \\
(\text { cwt } / \text { acre })^{\mathrm{z}} \\
\text { sand }\end{array}$ & $\begin{array}{c}\text { Simulated } \\
\text { yield } \\
\text { (cwt/acre) } \\
\text { sandy loam }\end{array}$ & $\begin{array}{c}\text { Observed } \\
\text { yield } \\
\text { (cwt/acre) }\end{array}$ \\
\hline \multicolumn{6}{|l|}{ Organic amendment } \\
\hline Bare soil (no organic inputs) & 0 & 0 & 29 & 28 & $\mathrm{ND}^{\mathrm{y}}$ \\
\hline Rye cover crop residues & 30 & 0 & 78 & 65 & ND \\
\hline Poultry manure & 250 & 0 & 318 & 237 & ND \\
\hline \multicolumn{6}{|l|}{ Organic amendment $+\mathrm{N}$ fertilizer } \\
\hline $\begin{array}{l}\text { Bare soil with recommended N fertilizer } \\
{\left[200 \mathrm{lb} / \text { acre }\left(224.2 \mathrm{~kg} \cdot \mathrm{ha}^{-1}\right)\right]}\end{array}$ & 0 & 200 & 420 & 390 & $265(31)^{x}$ \\
\hline $\begin{array}{l}\text { Bare soil with supra-optimum } \mathrm{N} \text { fertilizer } \\
{\left[235 \mathrm{lb} / \text { acre }\left(263.4 \mathrm{~kg} \cdot \mathrm{ha}^{-1}\right)\right]^{\mathrm{w}}}\end{array}$ & 0 & 235 & 610 & 457 & ND \\
\hline Rye cover crop residues & 30 & 190 & 484 & 414 & $278(42)$ \\
\hline Poultry manure & 250 & 160 & 644 & 540 & $359(46)$ \\
\hline
\end{tabular}


Soil was dried and ground to pass a 2 - $\mathrm{mm}(0.08$-inch $)$ sieve, and processed by A\&L Laboratories (Fort Wayne, Indiana) where particle size analysis was conducted by the hydrometer method after dispersing soil in sodium hexametaphosphate. Organic carbon was measured by a modified WalkleyBlack procedure (Snapp, 1998).

\section{Results and discussion}

Potato yield Response. Simulated and observed yield response of potatoes to $\mathrm{N}$ fertilizer rate, cover crop residues and manure is shown in Table 2 . Yields observed in the field experiment are typical for commercial production in the area, yet they are about one-third lower than the simulated yield data. For the field experiment and simulation we used the Michigan recommended level of $\mathrm{N}$ fertilizer $(200 \mathrm{lb} /$ acre $\mathrm{N}$ for mid-season cultivars on sandy, low organic matter sites; Snapp et al., 2002). Michigan research results indicate that $200 \mathrm{lb} /$ acre $\mathrm{N}$ is sufficient to optimize US\#1 tuber marketable yields in 'Atlantic' and 'Pike' (Silva et al., 1991; Snapp et al., 2003). However, model simulations using increased levels of $\mathrm{N}$ fertilizer in $25-\mathrm{lb}(11.3-\mathrm{kg})$ increments above $200 \mathrm{lb} /$ acre $\mathrm{N}$ indicated that a yield response was observed up until $250 \mathrm{lb} /$ acre $\mathrm{N}$, after which yield response leveled off and decreased slightly (data not shown).

Overestimation of yield has been observed previously for the DSSAT family of SUBSTOR simulation models (Griffin et al., 1993; Snapp et al., 2001). A much closer relationship of observed and simulated data has been shown for CROPGRO and CERES, the soybean and corn modules of DSSAT (Huffman et al., 2001; Sau et al., 1999). The SUBSTOR module apparently requires further modification to accurately simulate physiological responses of potato. Modeling of potato response is complicated due to the necessity to incorporate sensitivity to a relatively narrow temperature range, as moderately high temperature in the summer has negative effects on dry matter partitioning and tuber internal quality, whereas low temperatures in the fall limit the growth duration and yield potential of many cultivars (Lee et al., 1992). Simulation of potato production in the Pacific northwestern U.S. (PNW) by a cropping system model CropSyst was more successful, as Peralta and Stockle (2001) were able to predict yields to within $5 \%$ of observed yields. This may be due in part to the long growing season and favorable environment for potato production in the PNW that supports very high commercial yields, close to the optimum modeled.

Notwithstanding a consistent overestimation of potato yields, DSSAT predication of relative yield response to organic sources of varying quality was similar to that of observed responses (Table 2). Manure treatments were both higher quality and a larger quantity of organic $\mathrm{N}$ inputs, thus were expected to increase yields to a greater extent than the relatively low quality, low quantity cover crop treatments. It is interesting that DSSAT simulation predicted increased growth, $\mathrm{N}$ uptake and yields associated with manure+fertilizer treatments compared to fertilizer applied alone (Table 2; Fig. IA and B). It has been difficult for researchers to explain a similar trend seen in field experiments, where a consistent 50 to $75 \mathrm{cwt}$ ( 2268 to $3402 \mathrm{~kg}$ ) increase in potato yield is associated with incorporating $\mathbf{5 0 0 0}$ $\mathrm{lb} /$ acre of manure, compared to unmanured controls. This has been observed in four out of five mid-Michigan field experiments (Snapp et al., 2003). Extra $\mathrm{N}$ or micronutrients from the manure cannot be the entire explanation for the yield increase observed in the field, as recommended levels of all macro and micronutrients were applied, in addition to the manure treatment.

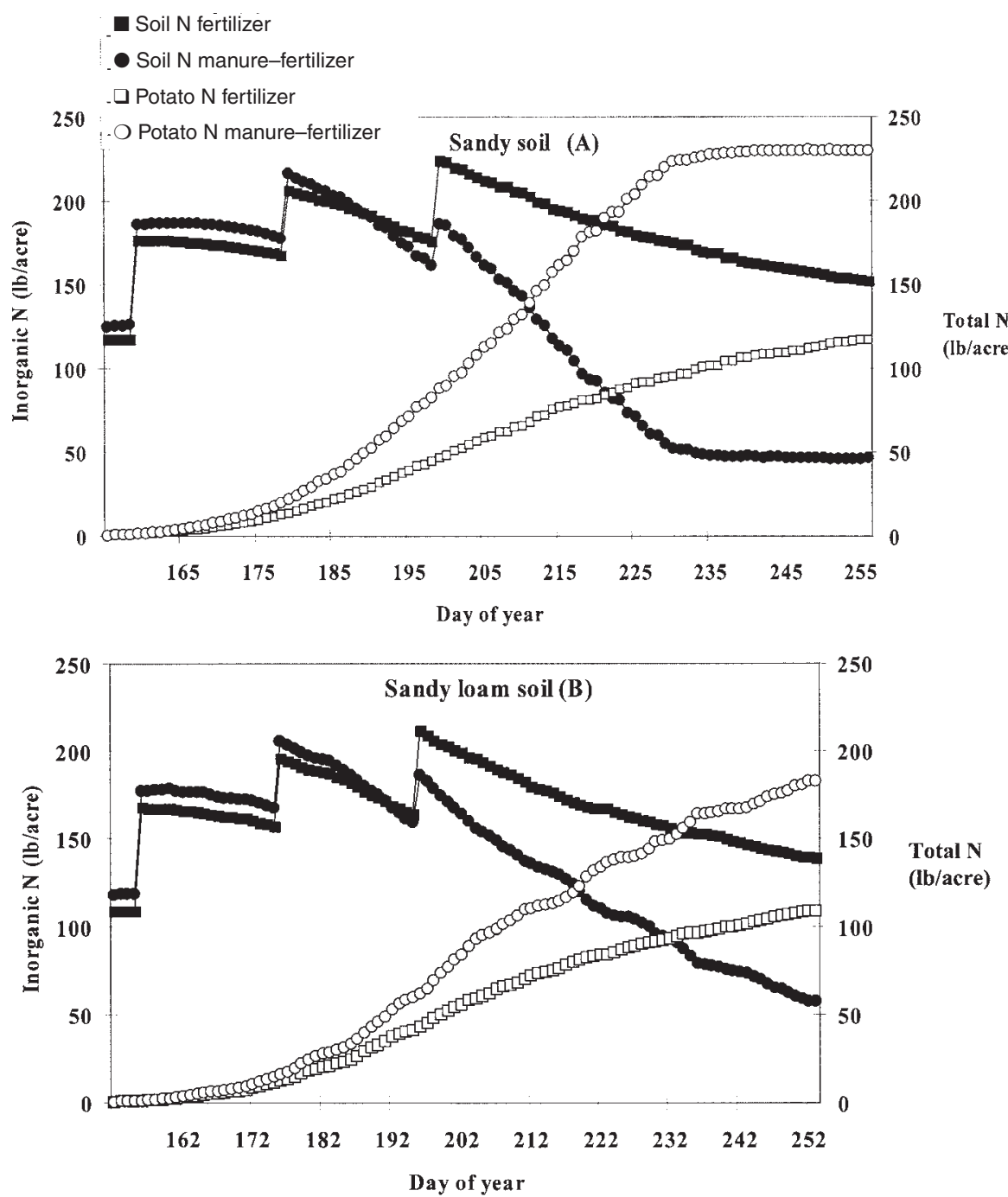

Fig. 1. Soil profile inorganic nitrogen (N) (ammonia plus nitrate) over the potato growing season from DSSAT simulations. (ם) Scenario with fertilizer $\mathbf{N}$ at 200 $\mathrm{lb} /$ acre and $(0)$ scenario with fertilizer $\mathrm{N}$ at $160 \mathrm{lb} /$ acre plus poultry manure at $5000 \mathrm{lb} /$ acre, $5 \%$ N. Plant $\mathrm{N}$ uptake is shown for the same simulations, with (D) fertilizer scenario and $(\bigcirc)$ fertilizer plus manure scenario. (A) Simulations run with a sandy soil, (B) Simulations run with a sandy loam soil. $1 \mathrm{lb} / \mathrm{acre}=1.12$ $\mathrm{kg} \cdot \mathrm{ha}^{-1}$. 

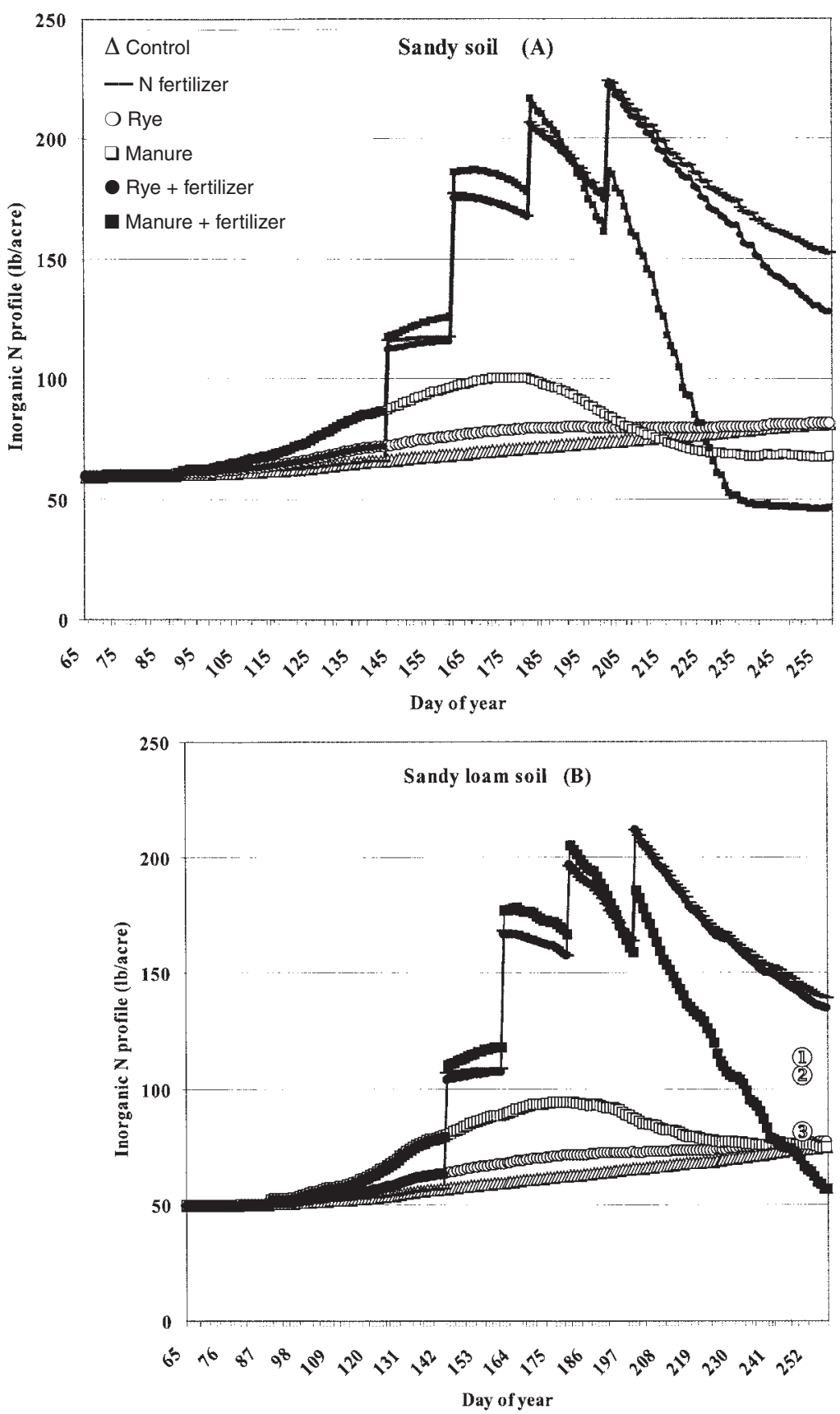

Fig. 2. Soil profile inorganic nitrogen $(\mathrm{N})$ (ammonia plus nitrate) over the potato growing season from DSSAT simulations of six fertility management regimes for potato production. Table 1 provides detailed information on the scenarios: $(\Delta)$ control with no inputs; ( $\square$ ) recommended $\mathrm{N}$ fertilizer rate at $200 \mathrm{lb} / \mathrm{acre}$; (○) rye cover crop as the $\mathrm{N}$ source; $(\square)$ poultry manure as the $\mathrm{N}$ source, $(0)$ rye cover plus fertilizer at $190 \mathrm{lb} /$ acre $\mathrm{N}$; (ם) poultry manure plus fertilizer at 160 $\mathrm{lb} / \mathrm{acre}$ N. (A) Simulations run with a sandy soil, (B) simulations run with a sandy loam soil. Observed data from field experiment shows inorganic- $\mathrm{N}$ from soil samples taken at harvest indicated by circled numbers: $j=$ fertilizer; $k=$ rye+fertilizer; 1 = manure+fertilizer. $1 \mathrm{lb} /$ acre $=1.12 \mathrm{~kg} \cdot \mathrm{ha}^{-1}$.

The DSSAT modeling exercise provides some insight into the yield benefitobserved with manure+fertilizer treatments. There was no simulated yield response (only a slight decrease) for fertilizer levels above $235 \mathrm{lb} /$ acre $\mathrm{N}$ (Table 2). Thus the higher amount of $\mathrm{N}$ applied with a manure + fertilizer characteristics would not be expected to change discernibly in the first year of application at the relatively moderate amount applied here, $5000 \mathrm{lb} /$ acre.

One explanation could be the synchrony of $\mathrm{N}$ supply from manure mineralization, compared to $\mathrm{N}$ demand in the plus manure treatment. In the sandy soil the manure plus $\mathrm{N}$ fertilizer treatment appeared to have particularly efficient transfer of $\mathrm{N}$ from manure treatment to plant uptake, with correspondingly high yields compared to the sandy loam soil module (Fig. 1A and B). Experimental results from a large container experiment support this as plant $\mathrm{N}$ uptake and soil nitrate levels in potato systems (monitored by ion-exchange resin) indicated close synchrony of supply and demand in manure plus $\mathrm{N}$ fertilizer treatments compared to $\mathrm{N}$ fertilizer alone (Nyiraneza, 2003).

SoIL N dynamics. Fertilizer N inputs were simulated by DSSAT as disjointed peaks in soil $\mathrm{N}$ over time, whereas organic source $\mathrm{N}$ release was simulated as smooth release curves in soil N over time (Fig. 2A). A comparison of soil inorganic $\mathrm{N}$ dynamics for the profile of a sand and a sandy loam was conducted (Fig. 2). Without inputs, the simulated initial soil inorganic $\mathrm{N}$ levels [ 6 to $8 \mathrm{lb} /$ acre $\left(6.7\right.$ to $\left.9.0 \mathrm{~kg} \cdot \mathrm{ha}^{-1}\right)$ in the topsoil] was similar to experimental observations for coarse textured soils with low organic carbon in the presence of a potato crop [5.5 lb/acre $(6.16$ $\mathrm{kg} \cdot \mathrm{ha}^{-1}$ ) soil inorganic-N]; Nyiraneza, 2003). The sandy soil was associated with slightly faster mineralization than that observed for the sandy loam, as expected due to the greater aeration that occurs in coarse textured soil. Observed levels of inorganic $\mathrm{N}$ in the soil profile at harvest were lower than the level simulated (Fig. 2B). In the PNW, fertility experiments conducted on commercial potato fields found levels of 120 to $140 \mathrm{lb} /$ acre (134.5 to 156.9 $\left.\mathrm{kg} \cdot \mathrm{ha}^{-1}\right)$ residual inorganic $\mathrm{N}$ at the end of the growing season (Weinert et al., 2002), similar to DSSAT simulations (Fig. 2). The pattern of response was similar between our field experiments and DSSAT simulations: fertilizer treatments with and without rye had the highest residual inorganic $\mathrm{N}$, and the treatment with combination of manure and $\mathrm{N}$ fertilizer had the lowest residual inorganic N (Fig. 2B). This is indicative of highly efficient use of $\mathrm{N}$ from the combined treatment of manure + $\mathrm{N}$ fertilizer. 


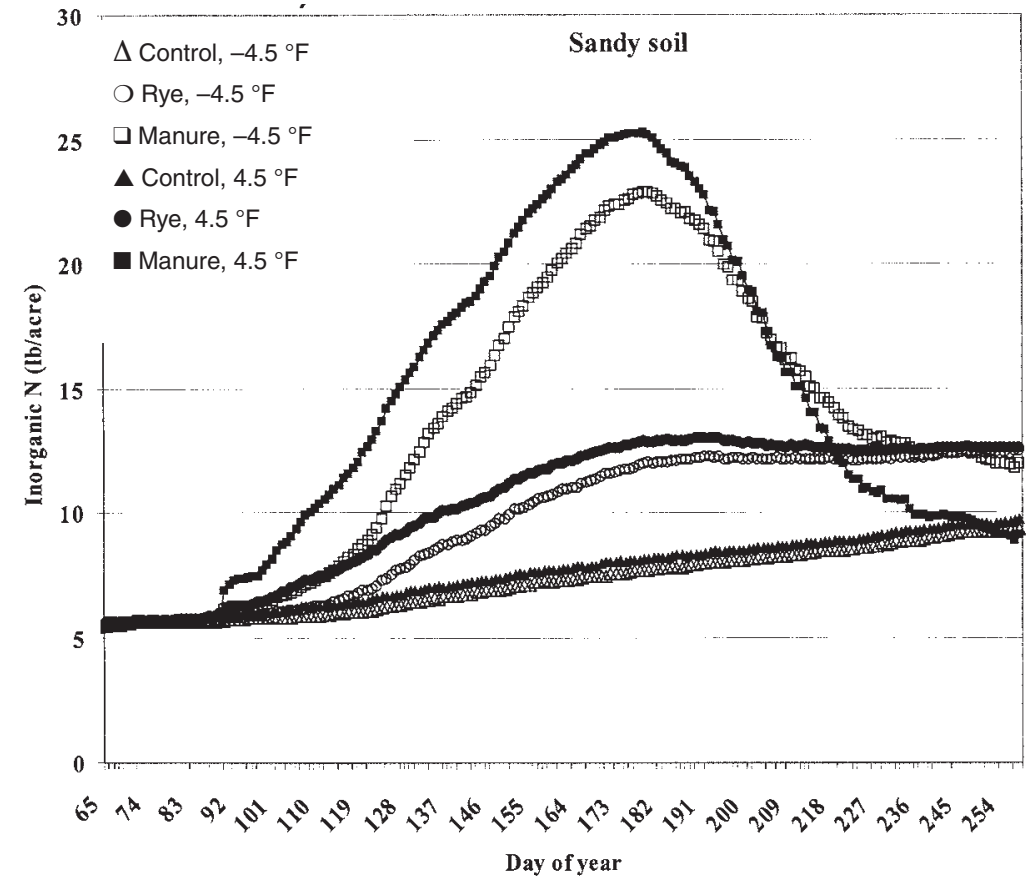

Fig. 3. Soil topsoil 0 to 6 inches $(0.15 \mathrm{~m})$ inorganic nitrogen $(\mathrm{N})$ (ammonia plus nitrate) over the potato growing season from DSSAT simulations of three fertility management regimes for potato production, conducted using unfilled symbols for a cool spring scenario $\left[-4.5^{\circ} \mathrm{F}\left(2.50^{\circ} \mathrm{C}\right)\right.$ from normal 1993 weather module] and filled symbols for a warm spring scenario $\left(4.5^{\circ} \mathrm{F}\right.$ added to 1993 weather $)$. Fertility management: $(\Delta)$ control with no input; $(\bigcirc)$ rye cover crop as the $N$ source; ( $(\square)$ poultry manure as the $\mathrm{N}$ source. $1 \mathrm{lb} /$ acre $=1.12 \mathrm{~kg} \cdot \mathrm{ha}^{-1}$.

If the combination of organic inputs with $\mathrm{N}$ fertilizer can improve the efficiency of $\mathrm{N}$ uptake by potatoes, these results should be considered in the on-going debate on how to improve $\mathrm{N}$ efficiency. A CropSyst simulation study of potato-corn-wheat systems in the PNW indicated that improving irrigation efficiency or increasing the number of split applications of fertilizer did not reduce leaching (Peralta and Stockle, 2001). The only means of reducing nitrate leaching in the simulation was to reduce the amount of $\mathrm{N}$ fertilizer applied; however organic inputs were assumed to remain at a low level in the study. Recent reviews have concluded that the only practical means to enhance efficiency and reduce leaching from irrigated systems is to reduce fertilizer $\mathrm{N}$ applied, and have suggested that the focus should be on fertilizer $\mathrm{N}$ management not organic $\mathrm{N}$ sources as inorganic $\mathrm{N}$ is the form plants take up (Cassman et al, 2002; Raun and Johnson, 1999). Yet if the addition of carbon with $\mathrm{N}$ has the net effect of altering availability of $\mathrm{N}$ in relationship to crop demand, this indicates that organic sources have the potential to improve $\mathrm{N}$ efficiency, although they can also lead to To optimize $\mathrm{N}$ efficiency and reduce leaching, $\mathrm{N}$ credits for organic inputs should be used to adjust fertilizer rates. This is reinforced by the findings here and an earlier simulation study which indicated that leaching potential can be reduced to $45 \mathrm{lb} /$ acre $\left(50.4 \mathrm{~kg} \cdot \mathrm{ha}^{-1}\right)$ $\mathrm{N}$ at harvest if $\mathrm{N}$ fertilizer credits are used (Snapp et al., 2001).

In irrigated, sandy soils the major environmental factor controlling mineralization is likely to be temperature as water, aeration and diffusion of carbon or nutrient substrates tend to be optitextured soils, typical of potato and vegetable sites. To evaluate temperature effects for Michigan conditions, we conducted DSSAT simulations that compared $\mathrm{N}$ mineralization in the topsoil using a cool spring weather file of minus $4.5^{\circ} \mathrm{F}$ lower than normal temperatures (NOAA, 2003) and a warm spring scenario of plus $4.5^{\circ} \mathrm{F}$ (Fig. 3 ). The most dramatic effect was on manure mineralization, which was shifted to approximately $10 \mathrm{~d}$ earlier. The low quality and quantity organic treatment and bare soil did not mineralize large amounts of $\mathrm{N}$, thus differences in $\mathrm{N}$ availability were slight (Fig. 3). asynchrony through immobilization. mized in irrigated systems with coarse
Thermal units have been used to predict $\mathrm{N}$ availability from residues and manure, with a cut off for activity at about $50{ }^{\circ} \mathrm{F}\left(10.0^{\circ} \mathrm{F}\right)$ (Griffin and Honeycutt, 2000; Honeycutt and Potaro, 1990), and DSSAT simulations use similar empirically derived relationships, thus no significant mineralization was shown for $90 \mathrm{~d}$ after 1 Jan., even in a warm spring scenario (Fig. 3). However, the relationship of thermal units and mineralization may depend in part on the soil microbial communities present. Two recent field experiments indicate that significant mineralization occurs over the winter season, in Norway (Henriksen and Breland, 1999) and in PNW commercial potato fields (Weinert et al., 2002). An incubation study found that $\mathrm{N}$ mineralization from manure and respiration occurred over $80 \mathrm{~d}$ at winter temperatures close to $0{ }^{\circ} \mathrm{C}\left(32^{\circ} \mathrm{F}\right)$ (Chantigny, 2002). The phenomena of mineralization in cold conditions is not represented by DSSAT.

From our results it appears that for Michigan temperatures and sandy soils the most important factor determining inorganic $\mathrm{N}$ supply will be the quality and quantity of organic inputs, not the ambient temperature. This remains to be tested in the field. It is suggestive that research attention should be targeted to developing prediction tools that relate organic input quality to mineralization, rather than attention to thermal units for predictive purposes, at least for this environment. It is also possible that DSSAT subroutines underestimate the effect of temperature on mineralization, although overestimation of inorganic $\mathrm{N}$ levels and production potential is what we observed.

\section{Conclusions}

The DSSAT sub-routine SUBSTOR and soil and water modules captured the relative mineralization rates and potato $\mathrm{N}$ uptake for six $\mathrm{N}$ fertility scenarios, with and without organic sources. Total yield and soil inorganic $\mathrm{N}$ accumulation at the end of the season were overestimated in the simulations, compared to field experiments. Simulations conducted with Michigan weather and soil conditions indicated that the rate of soil inorganic $\mathrm{N}$ accumulation from organic inputs was faster by about $10 \mathrm{~d}$ in a warm spring compared to a cool spring. For the limited number of scenarios tested here, the most important factor determining inorganic $\mathrm{N}$ supply was the 
quality and quantity of organic inputs, not temperature. The combination of a high quality organic and an inorganic $\mathrm{N}$ source was highly efficient at optimizing potato yields while reducing the leachable nitrate pool at the end of the season. This supports the need for improved decision aides that assist growers in accurately predicting $\mathrm{N}$ supply dynamics for organic sources.

\section{Literature cited}

Cassman, K.G., A. Dobermann, and D.T. Walters. 2002. Agroecosystems, nitrogen-use efficiency and nitrogen management. Ambio 31:132-140.

Chantigny, 2002. Fate of carbon and nitrogen from animal manure and crop residues in wet and cold soils. Soil Biol. Biochem. 34:509-517.

Christenson, D., D. Warncke, M. Vitosh, L. Jacobs, and J. Dahl. 1992. Fertilizer recommendations for field crops in Michigan. Mich. State Univ. Ext. Bul. E550-A.

Chu, M.C., S.M. Swinton, S.S. Batie, and C. Dobbins. 1997. Agricultural production contracts to reduce nitrate leaching: A wholefarm analysis. Taiwanese Agr. Econ. Rev. 2: 163-185.

Gale, P.M. and J.T. Gilmour. 1986. Carbon and nitrogen mineralization kinetics for poultry litter. J. Environ. Qual. 15:423-426.

Godwin, D.C. and C.A. Jones. 1999. Nitrogen dynamics in soil-plant systems, p. 292-295. In: J.H. Hanks and J.T. Ritchie (eds.). Modeling plant and soil systems. Agron. Monogr. 31. ASA-CSSA-SSSA, Madison, Wis.

Griffin, T.S. and O.B. Hesterman. 1991. Potato response to legume and fertilizer $\mathrm{N}$ sources. Agron. J. 83:1004-1012.

Griffin, T.S. and C.W. Honeycutt. 2000. Using growing degree days to predict $\mathrm{N}$ availability from livestock manures. Soil Sci. Soc. Amer. J. 64:1876-1882.

Griffin, T.S., B.S. Johnson, and J.T. Ritchie. 1993. A simulation model for potato growth and development: SUBSTOR-Potato version 2.0. Intl. Benchmark Sites Network Agrotechnol. Transfer (IBSNAT) Res. Rpt. Ser. vol. 02.

Haverkort, A.J. and D.K.L. MacKerron. 2000. Management of nitrogen and water in potato production. Wageningen Pers, Wageningen, The Netherlands.

Henriksen, T.M. and T.A. Breland. 1999. Decomposition of crop residues in the field: Evaluation of a simulation model developed from microcosm studies. Soil Biol. Biochem. 31:1423-1434.

Honeycutt, C.W. and L.J. Potaro. 1990. Field evaluation of heat units for predicting crop residue carbon and $\mathrm{N}$ mineralization. Plant Soil 125:213-220.
Huffman, E.C., J.Y. Yang, S. Gameda and R. de Jong. 2001. Using simulation and budget models to scale-up $\mathrm{N}$ leaching from field to region in Canada, p. 699-706 In: J. Galloway, E. Cowling, J.W. Erisman, J. Wisnieswki and C. Jordan (eds.). Optimizing nitrogen management in food and energy production and environmental protection. 2nd Intl. N Conf. Papers, A.A. Balkema Publ. Lisse/Abingdon/Exton/Tokyo.

Jansson, S.L. and J. Persson. 1982 . Mineralization and immobilization of soil N, p. 229-248. In: F.J. Stevenson (ed.). Nitrogen in agricultural soils. Amer. Soc. Agron. Monogr. 22.

Lang, N.S., R.G. Stevens, R.E. Thornton, W.L. Pan and S. Victory. 1999. Potato nutrient management for central Washington. Wash. State Univ., Pullman, Coop. Ext. Bul. 1871.

Lee, G.S., S.B. Sterrett, and M.R. Henninger. 1992. A heat-sum model to determine yield and onset of internal heat necrosis for atlantic potato. Amer. Potato J. 69:353-362.

Linn, D.M. and J.W. Doran. 1984. Effect of water-filled pore space on carbon dioxide and nitrous oxide production in tilled and non-tilled soils. Soil Sci. Soc. Amer. J. 48:1267-1272.

Love, S.L. 1999. Founding clones, major contributing ancestors, and exotic progenitors of prominent North American potato cultivars. Amer. J. Potato Res. 76:263-272.

National Oceanic and Atmospheric Administration. 2003. National Climatic Data Center. 25 June 2003. <http://www.ncdc.noaa.gov/oa/ ncdc.html>.

Nyiraneza, J. 2003. Manure and cover crop effects on nitrogen dynamics in irrigated potato systems. MS thesis. Mich. State Univ., East Lansing.

Ojala, J.C., J.C. Stark, and G.E. Kleinkopf. 1990. Influence of irrigation and $\mathrm{N}$ management on potato yield and quality. Amer. Potato J. 67:29-44.

Olness, A., D. Lopez, D. Archer, J. Cordes, C. Sweeney, N. Mattson, J. Rinke, and W.B. Voorhees. 2001. Factors affecting microbial formation of nitrate- $\mathrm{N}$ in soil and their effects on fertilizer N-use efficiency, p. 122-129. In: J. Galloway, E. Cowling, J.W. Erisman, J. Wisnieswki and C. Jordan (eds.). Optimizing nitrogen management in food and energy production and environmental protection. 2nd Intl. N Conf. Papers, A.A. Balkema Publ. Lisse/Abingdon/ Exton/Tokyo.

Opena, G.B. and G.A. Porter. 1999. Soil management and supplemental irrigation effects on potato: II. Root growth. Agron. J. 91:426-431.

Paz, J.O., W.D. Batchelor, B.A. Babcock, T.S. Colvin, S.D. Logsdon, T.C. Kasparm, and D.L. Karlen. 1999. Model-based technique to determine variable rate $\mathrm{N}$ for corn. Agr. Syst. 61:69-75.

Peralta, J.M. and C.O. Stockle. 2001. Dynamics of nitrate leaching under irrigated potato rota- tion in Washington State: a long-term simulation study. Agr. Ecosystem Environ. 88:23-34

Raun, W.R. and G.V. Johnson. 1999. Improving $\mathrm{N}$ use and efficiency for cereal production: Review and interpretation. Agron. J. 91: 357-363.

Rosen, C. 1991. Potato fertilization on irrigated soils. vol. 2002. FO-3425-GO. Commun. Educ. Technol. Serv., Univ. Minn. Ext. Serv.

Sau, F., K.J. Boote, and B. Ruiz-Nogueira. 1999. Evaluation and improvement of CROPGROsoybean model for a cool environment in northwest Spain. Field Crop Res. 61:273-291.

Schmitt, M.A., M.P. Russelle, G.W. Randall, and J.A. Lory. 1999. Manure N crediting and management in the USA: Survey of university faculty. J. Prod. Agr. 12:419-422.

Silva, G.H., R.W. Chase, R. Hammerschmidt, M.L.Vitosh, and R.B. Kitchen. 1991. Irrigation, nitrogen and gypsum effects on specific gravity and internal defects of Atlantic potatoes. Amer. Potato J. 68:751-765.

Snapp, S.S. 1998. Soil nutrient status of smallholder farms in Malawi. Comm. Soil Sci. Plant Anal. 29:2571-2588.

Snapp, S.S., H. Borden, and D.D. Rohrbach. 2001. Improving nitrogen efficiency: Lessons from Malawi and Michigan, p. 42-48. In: J. Galloway, E. Cowling, J.W. Erisman, J. Wisnieswki and C. Jordan (eds.). Optimizing nitrogen management in food and energy production and environmental protection. 2nd Intl. N Conf. Papers. A.A. Balkema Pub. Lisse/Abingdon/ Exton/Tokyo.

Snapp, S.S., D. Smucker, and M. Vitosh. 2002. Nitrogen management for Michigan potatoes, Michigan State University Extension Bulletin E2779.

Snapp, S.S., J. Nyiranez, and K. O’Neil. 2003. Organic inputs and a cover crop-short rotation for improved potato productivity and quality. In: Michigan potato research report. vol. 34 . Mich. State Univ. Agr. Expt. Sta.-Mich. Potato Ind. Comm., East Lansing.

Tsuji, G.Y., G. Uehara, and S. Balas. 1994. DSSAT version 3.0: A decision support system for agrotechnology transfer. vol. 1-3. Intl. Benchmark Sites Network for Agrotechnol. Transfer (IBSNAT) Res. Rpt. Ser., Univ. Hawaii.

Vitosh, M. L., D.R. Smucker, J.M. Middleton and D. Glenn. 1998. Nitrogen stewardship practices to reduce nitrate leaching and sustain profitability in an irrigated potato production system, p. 60-76. In: Michigan potato research report. vol. 30. Mich. State Univ. Agr. Expt. Sta.-Mich. Potato Ind. Comm., East Lansing.

Weinert, T.L., W.L. Pan, M.R. Moneymaker, G.S. Santo, and R.G. Stevens. 2002. Nitrogen recycling by nonleguminous winter cover crops to reduce leaching in potato rotations. Agron. J. 94:365-372. 